\title{
Mesenchymal stem cells provide prophylaxis against acute graft-versus-host disease following allogeneic hematopoietic stem cell transplantation: A meta-analysis of animal models
}

\author{
Li Wang ${ }^{1,2, *}$, Haiyan Zhang ${ }^{3, *}$, Lixun Guan ${ }^{1}$, Shasha Zhao ${ }^{1}$, Zhenyang Gu ${ }^{1}$, Huaping \\ Wei $^{1}$, Zhe Gao ${ }^{1}$, Feiyan Wang ${ }^{1}$, Nan Yang${ }^{1}$, Lan Luo ${ }^{1}$, Yonghui Li $^{1}$, Lili Wang ${ }^{1}$, \\ Daihong Liu ${ }^{1}$, Chunji Gao ${ }^{1}$ \\ ${ }^{1}$ Department of Hematology, Chinese People's Liberation Army (PLA) General Hospital, Beijing, China \\ ${ }^{2}$ Department of Hematology and Oncology, Laoshan Branch, No. 401 Hospital of Chinese PLA, Qingdao, China \\ ${ }^{3}$ Department of Hematology, Linyi People's Hospital, Linyi, China \\ *These authors have contributed equally to this work \\ Correspondence to: Chunji Gao, email: gaochunji@medmail.com.cn \\ Keywords: mesenchymal stem cells, graft-versus-host disease, hematopoietic stem cell transplantation, meta-analysis, animal \\ experimentation \\ Received: April 30, $2016 \quad$ Accepted: July 28, $2016 \quad$ Published: August 12, 2016
}

\section{ABSTRACT}

A meta-analysis of animal models was conducted to evaluate the prophylactic effects of mesenchymal stem cells (MSCs) on acute graft-versus-host disease (aGVHD) after allogeneic hematopoietic stem cell transplantation. A total of $\mathbf{5 0}$ studies involving 1848 animals were included. The pooled results showed that MSCs significantly reduced aGVHD-associated mortality (risk ratio $=0.70,95 \%$ confidence interval 0.62 to $0.79, P=2.73 \times 10^{-9}$ ) and clinical scores (standardized mean difference $=\mathbf{- 3 . 6 0}$, $95 \%$ confidence interval -4.43 to $\left.-2.76, P=3.61 \times 10^{-17}\right)$. In addition, MSCs conferred robust favorable prophylactic effects on aGVHD across recipient species, MSC doses, and administration times, but not MSC sources. Our meta-analysis showed that MSCs significantly prevented mortality and alleviated the clinical manifestations of aGVHD in animal models. These data support further clinical trials aimed at evaluating the efficacy of using MSCs to prevent aGVHD.

\section{INTRODUCTION}

Allogeneic hematopoietic stem cell transplantation (allo-HSCT) is the only curative modality for many hematological malignancies. The number of patients undergoing this procedure is rapidly increasing because of the development of novel allo-HSCT strategies and improved supportive treatments [1]. However, lifethreatening complications, especially acute graft-versushost disease (aGVHD), are frequently encountered after allo-HSCT and can limit the widespread use and success of this important therapy $[1,2]$. Currently, a variety of prophylactic strategies, including T-cell depletion and immunosuppressive agents, are used to prevent aGVHD. However, T-cell depletion impairs the graftversus-leukemia effect and has been associated with an increased rate of primary disease relapse [1]. Furthermore, pharmacological strategies are associated with impaired immune reconstitution in recipients [3]. Therefore, novel prophylactic strategies for aGVHD are urgently needed.

Mesenchymal stem cells (MSCs) are considered ideal candidates for cell therapy during allo-HSCT because of their unique immunomodulatory and reparative properties [4]. MSCs are currently generating significant interest because they confer potential prophylactic effects against aGVHD following allo-HSCT [5, 6], and several relevant randomized controlled trials (RCTs) have been published [7-10]. However, the results of these studies have been inconsistent. Ning et al. [7] reported that the rate of grade II-IV aGVHD was significantly lower in an MSC-infused group than in the control group (11.1\% versus $53.3 \%$, respectively), whereas Liu et al. [8] reported that a higher rate of aGVHD was observed when participants received infusions of MSCs $(51.8 \%$ versus 
$38.9 \%$ compared to recipients who did not receive MSCs). Because these studies included small sample sizes and their results were conflicting, our and other groups have conducted meta-analyses of relevant clinical trials, but the results have not indicated that the adoptive transplantation of MSCs prevents aGVHD $[11,12]$.

MSCs have been extensively studied in animal models as a prophylactic strategy against aGVHD after allo-HSCT. Similar to clinical trials, studies using animal models have produced conflicting results. Here, we perform the first meta-analysis of these animal models to provide recommendations for designing future clinical trials.

\section{RESULTS}

\section{Study selection and characteristics}

We identified a total of 2305 potentially relevant studies. After removing duplicates and screening article titles and abstracts, 2167 non-relevant studies were excluded. The full texts of the remaining 138 studies were screened. This led to the exclusion of an additional 88 studies that did not meet the eligibility criteria. The excluded full-text studies and the reasons for their exclusion are listed in Supplementary Table 1. Finally, 50 studies involving 1848 animals (1067 MSC recipients and 781 controls) and 93 and 41 comparisons that assessed aGVHD mortality and clinical scores, respectively, were included in the meta-analysis (Supplementary Figure 1) [13-62]. The majority of the studies used a previously described clinical scoring system [63] to assess the severity of aGVHD (a higher clinical score indicates more severe aGVHD). The characteristics of the included studies are listed in Tables 1 and Supplementary Table 2.

\section{Methodological quality evaluation}

Five studies reported that animals were randomly assigned to an MSC or control group [13, 19, 33, 38, 44], and four studies indicated that the assessors were blinded to outcomes $[15,45,53,58]$. The majority of the included studies reported compliance with animal welfare requirements and conflict of interest statements. However, none of the included studies mentioned allocation concealment or sample size calculations (Tables 2 and Supplementary Table 3).

\section{Meta-analysis}

A total of 49 studies involving 93 comparisons examined the effect of MSCs on aGVHD-associated mortality in animal models of allo-HSCT [13-48, 5062]. The pooled results indicated that aGVHD-associated mortality was significantly lower in the MSC groups than in the control groups $(\mathrm{RR}=0.70,95 \% \mathrm{CI} 0.62$ to $0.79, P=$ $\left.2.73 \times 10^{-9}\right)$ (Figure 1). There was significant heterogeneity among the studies $\left(\mathrm{I}^{2}=66.1 \%, P=2.12 \times 10^{-18}\right)$ (Figure 1$)$.
In addition, 29 studies involving 41 comparisons examined the effect of MSCs on aGVHD-associated clinical scores $[14,15,17,19,20,22,24,27,28,33,34,36-39,42,44$, $46,47,49-52,55,57-59,61,62]$. The pooled analysis indicated that aGVHD-associated clinical scores were significantly lower in the MSC groups than in the control groups $(\mathrm{SMD}=-3.60,95 \% \mathrm{CI}-4.43$ to $-2.76, P=3.61 \times 10$ ${ }^{17}$ ) (Figure 2 ). There was significant heterogeneity among the studies $\left(\mathrm{I}^{2}=92.8 \%, P=2.26 \times 10^{-92}\right)$ (Figure 2$)$.

\section{Subgroup meta-analysis and meta-regression}

Because there was significant heterogeneity among the studies, we conducted a subgroup meta-analysis using the following factors: recipient species, MSC source, MSC dose and administration time. We included only variables for which more than two comparisons were made. The subgroup meta-analysis demonstrated that MSCs provided similar beneficial prophylactic effects on the mortality and severity of aGVHD based on the recipient species, MSC dose and administration time (Supplementary Tables 4 and 5). In the MSC source data, the rate of aGVHD-associated mortality was significantly lower in groups administered mouse bone marrow (BM)-, human BM- and human umbilical cord blood (UCB)-derived MSCs than in the control groups $(\mathrm{RR}=0.77,95 \% \mathrm{CI} 0.65$ to 0.91 ; $\mathrm{RR}=$ $0.68,95 \%$ CI 0.51 to 0.93 ; $\mathrm{RR}=0.56,95 \%$ CI 0.37 to 0.85 , respectively) (Supplementary Table 4). However, there were no significant group differences when adipose tissue- and umbilical cord (UC)-derived MSCs were compared to the control group $(\mathrm{RR}=0.49,95 \% \mathrm{CI} 0.23$ to 1.06 ; $\mathrm{RR}=0.51$, $95 \%$ CI 0.20 to 1.31 , respectively) (Supplementary Table 4). Consistent with the aGVHD mortality results, aGVHD clinical scores were significantly lower in the groups that received mice BM-, human BM-, and human UCB-derived MSCs than in the control group, and there was no significant difference between the human adipose tissue-derived MSC group and the control group (Supplementary Table 5).

To identify the potential source of heterogeneity, we conducted a meta-regression based on the factors mentioned above. The results indicated that the MSC source and dose accounted for a significant proportion of the heterogeneity in aGVHD-associated mortality (adjusted $\mathrm{R}^{2}=5.41 \%$ and $1.73 \%$, respectively) (Supplementary Table 4).

\section{Publication bias}

Funnel plots based on both aGVHD mortality and clinical scores showed asymmetry, suggesting the presence of publication bias (Figure 3). A subsequent Egger's test confirmed the existence of publication bias $\left(P=4.07 \times 10^{-6}\right.$, $P=0.001$, respectively).

Small-study effects may contribute to the asymmetry observed in the funnel plots (Figure 3). However, the beneficial effect of MSCs on aGVHD 
Table 1: Characteristics of the included studies

\begin{tabular}{lc}
\hline Characteristics & No. of comparisons \\
\hline No. of publications & 50 \\
No. of MSC arms & 94 \\
Species receiving MSCs & 7 \\
Rat & 87 \\
Mouse & \\
MSC sources & 7 \\
Rat BM & 48 \\
Mouse BM & 13 \\
Human BM & 9 \\
Human UCB & 4 \\
Human UC & 3 \\
Mouse adipose tissue & 2 \\
Human adipose tissue & 1 \\
Human menstrual blood & 1 \\
Mouse skin & 27 \\
Human decidua & 4 \\
Human placenta & 21 \\
Range of MSC doses & $2102 \times 10^{6}$ to $20 \times 10^{6}$ \\
MSC administration time & \\
Co-transplantation with allo-HSCT & 46 \\
Multiple doses including co-transplantation & 21 day post-allo-HSCT \\
Single or multiple doses, & \\
\hline
\end{tabular}

Abbreviations: BM, bone marrow; UCB, umbilical cord blood; UC, umbilical cord.

Table 2: Methodological quality of the included studies

\begin{tabular}{lc}
\hline Quality score criterion & Proportion of studies (\%) \\
\hline Published in peer-reviewed journal & 100 \\
Randomization & 10 \\
Allocation concealment & 0 \\
Blinding of outcome assessors & 8 \\
Estimation of sample sizes & 0 \\
Compliance with animal welfare requirement & 82 \\
Conflict of interest statement & 64 \\
\hline
\end{tabular}

mortality was similar between fixed- and random-effects models (Supplementary Table 6), implying that smallstudy effects did not substantially affect final estimates [64]. Moreover, no study was added in the trim and fill analysis. Thus, the funnel plot asymmetry may have been associated with other types of bias.

\section{DISCUSSION}

To our knowledge, this is the first meta-analysis to evaluate the prophylactic effects of MSCs on aGVHD in animal models of allo-HSCT. This meta-analysis indicates that MSCs significantly prevent mortality and alleviate the 


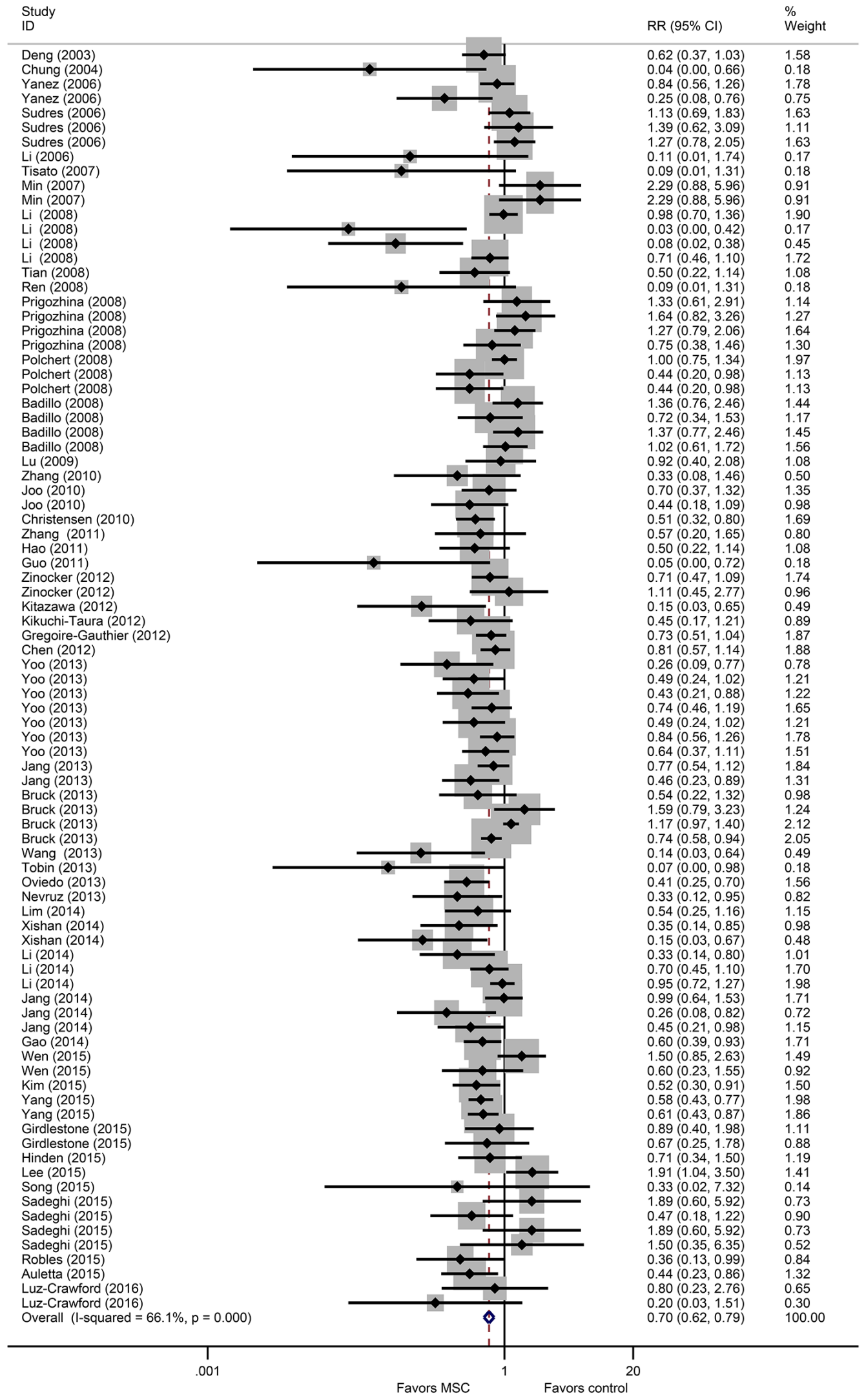

Figure 1: The prophylactic effect of MSCs on aGVHD mortality following allo-HSCT. MSCs: mesenchymal stem cells, aGVHD: acute graft-versus-host disease, allo-HSCT: allogeneic hematopoietic stem cell transplantation, RR: risk ratio, CI: confidence interval. 


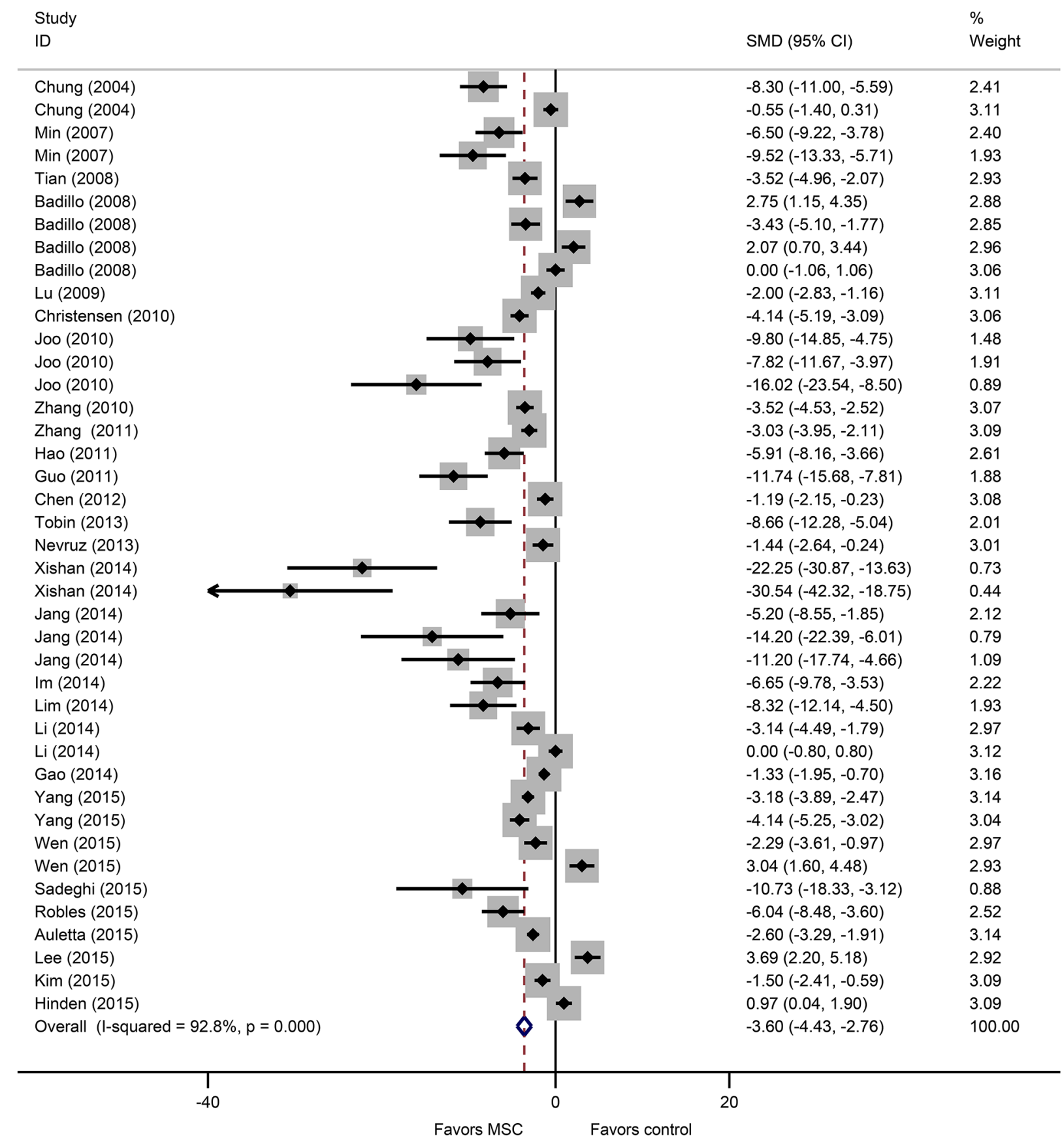

Figure 2: The prophylactic effect of MSCs on aGVHD clinical scores following allo-HSCT. MSCs: mesenchymal stem cells, aGVHD: acute graft-versus-host disease, allo-HSCT: allogeneic hematopoietic stem cell transplantation, SMD: standardized mean difference, CI: confidence interval.

clinical manifestations of aGVHD in animals that undergo allo-HSCT. In addition, MSCs provided robust favorable prophylactic effects against aGVHD across recipient species, MSC doses and administration times.

It should be noted that this meta-analysis included only mice and rats because few large animal studies are available. Several clinically relevant parameters, including the MSC source, dose and administration time, may have contributed to the heterogeneity and inconsistent results observed in these studies. We therefore conducted a subgroup meta-analysis based on these factors. One study reported that MSCs suppress immune responses only in an inflammatory environment [65], raising the question of whether co-transplanting MSCs with grafts may prevent aGVHD. The results of the subgroup meta-analysis indicated that co-transplanting MSCs had a prophylactic effect that was similar to the effect of infused MSCs administered more than one day after allo-HSCT. Our 

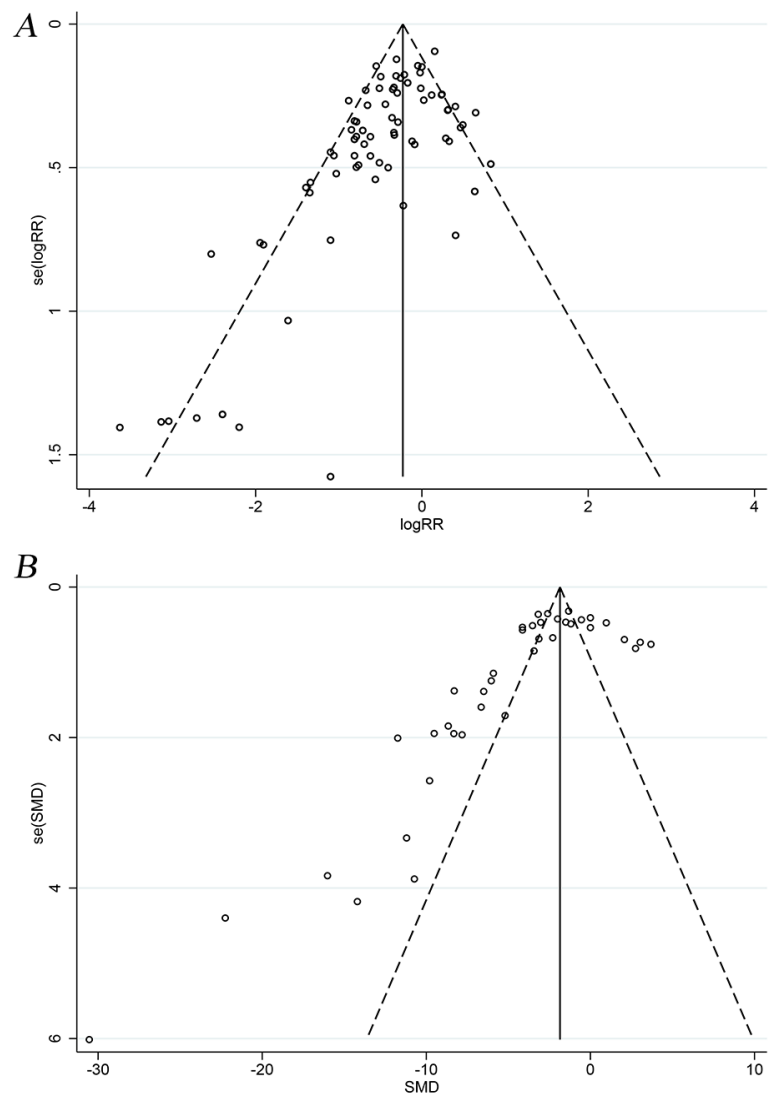

Figure 3: Funnel plots of aGVHD mortality and clinical scores. A. Funnel plot of aGVHD mortality. B. Funnel plot of aGVHD clinical scores. aGVHD: acute graft-versus-host disease.

subgroup meta-analysis demonstrated that MSCs produced a better prophylactic effect when administered at relatively high doses, consistent with another study that evaluated the effects of increasing doses of MSCs [40]. However, this dose-response effect may not be beneficial when the MSC dose is above a threshold [66]. Furthermore, the results of the subgroup meta-analysis seemed to suggest that differences might be based on the MSC source because favorable prophylactic effects were observed for BM- and UCB-derived MSCs but not adipose tissue- and UC-derived MSCs. Subsequent meta-regression analyses have consistently indicated that the MSC source is a significant contributor to heterogeneity. However, these results should be interpreted with caution because only a small number of relevant studies were included in the analysis.

A number of questions should be considered when translating these results into clinical trials. First, this meta-analysis focused on un-manipulated MSCs. Therefore, whether genetically modified or cytokine pre-treated MSCs are superior to un-manipulated MSCs as aGVHD prophylactics warrants further investigation. Second, cryopreserved MSCs may exert smaller immunomodulatory effects than freshly harvested cells [67]. However, we cannot directly compare cryopreserved
MSCs to fresh MSCs because of the limited number of available studies. Third, whether cell senescence impairs the immunomodulatory effects of MSCs remains unclear. Fourth, this meta-analysis exhibited publication bias that was often associated with overestimations of the efficacy of the intervention. We acknowledge this is a limitation of this meta-analysis. Finally, while murine models cannot fully replicate the pathophysiology of human aGVHD $[68,69]$, such models are useful because they increase our understanding of GVHD and provide a basis for forming clinically translatable ideas [69].

In summary, in this meta-analysis, we show that MSCs significantly prevent mortality and alleviate the clinical manifestations of aGVHD in animal models, supporting further investigations into the use of MSCs as prophylactics against aGVHD in clinical trials.

\section{MATERIALS AND METHODS}

\section{Search strategy}

A systematic literature search of PubMed and the Excerpta Medica Database (Embase) was conducted to identify studies published before February 2016 using the following key word search terms: "mesenchymal stem 
cell", "mesenchymal stromal cell", "MSC", "graft versus host", "graft vs host" and "GVHD". The language was restricted to English. The detailed search criteria are listed in Supplementary Tables 7 and 8. Relevant controlled studies evaluating the prophylactic effect of MSCs on aGVHD in rat or mouse models of allo-HSCT were identified. In addition, the reference lists of all identified studies were manually searched.

\section{Selection criteria}

Two independent researchers evaluated all potentially relevant studies. After titles/abstracts were screened, all suspect articles were submitted to full-text screening to avoid discarding relevant reports. All controlled studies that evaluated the prophylactic efficacy of MSC adoptive transplantation in aGVHD in rat or mouse models of alloHSCT and that reported aGVHD mortality or aGVHD clinical score outcomes, regardless of animal age, sex or strain, were included. Control interventions included saline, culture medium and no treatment.

Studies using manipulated MSCs (i.e., MSCs genetically modified to overexpress particular molecules or MSCs pre-treated with cytokines) were excluded. Furthermore, studies using MSCs concomitantly with other cell types or other therapies were also excluded. Because we were interested only in the prophylactic effects of MSCs on aGVHD, studies evaluating therapeutic effects of MSCs on established aGVHD were excluded. All discrepancies were resolved by consulting with a specialist.

\section{Data extraction}

Two researchers independently extracted the data. All related data, including reference details (the first author and publication year), donor animals (species and strain), recipient animals (strain, age and sex), graft, sample size, MSC source (donor species and tissue origin), MSC dose, administration time and the above-mentioned outcomes (aGVHD mortality and aGVHD clinical scores), were extracted.

The corresponding authors were contacted if the data were incomplete (i.e., if values for the mean and standard deviations (SD) were not reported). If no response was received from the corresponding authors, the values for the means and SDs were calculated from graphs in the original articles using digital ruler software. If a single study compared different MSC doses and/or administration times using one control group, the data were treated as independent comparison experiments, and the control group was divided by the number of experimental groups to ensure that the total number of controls was not changed [70]. If aGVHD clinical scores were serially monitored, only the data for the time point at which the most severe aGVHD manifestations developed were extracted.

\section{Methodological quality evaluation}

Two researchers independently assessed the methodological quality of each included study using previously reported criteria [70], with slight modifications. These criteria included seven items: peer-reviewed publication, randomization, concealment of allocation, blindness to outcome assessors, estimation of sample size, compliance with animal welfare requirements and conflict of interest statements.

\section{Statistical analysis}

Statistical analyses were performed using Stata software (version 12.0, Stata Corporation, College Station, TX, USA). A risk ratio (RR) and 95\% confidence interval (CI) were used to pool the aGVHD mortality data. Furthermore, because the clinical scoring system differed between studies, the standardized mean difference (SMD) and 95\% CI were used to pool the aGVHD clinical score data. Statistical heterogeneity among studies was assessed using the $\mathrm{I}^{2}$ statistic. Values of $\mathrm{I}^{2}>50 \%$ and $P<0.1$ indicated significant heterogeneity among the studies. Next, to reveal the potential source of statistical heterogeneity, we conducted a subgroup meta-analysis and univariate meta-regression based on the following clinical variables: recipient species, MSC source, MSC dose and administration time. The DerSimonian and Laird randomeffects model was used to provide more conservative conclusions when anticipated significant heterogeneity was identified among the included studies [71]. Funnel plots were constructed to examine the potential publication bias [72]. If funnel plot asymmetry was found, Egger's tests were conducted to confirm the existence of publication bias [73], and the asymmetry was adjusted using the Duval and Tweedie trim and fill analysis [74]. A $P$ value of less than 0.05 was considered statistically significant.

\section{CONFLICTS OF INTEREST}

The authors have no conflicts of interest to declare.

\section{GRANT SUPPORT}

This study was supported by the National Natural Science Foundation of China (81270642; 81070451), the Beijing Natural Science Foundation (7162175) and the Hainan Social Development Special Funding (SF201306).

\section{REFERENCES}

1. Ferrara JL, Levine JE, Reddy P, Holler E. Graft-versus-host disease. Lancet. 2009; 373: 1550-1561.

2. Holtan SG, Pasquini M, Weisdorf DJ. Acute graft-versushost disease: a bench-to-bedside update. Blood. 2014; 124 : 363-373. 
3. Imado T, Iwasaki T, Kataoka Y, Kuroiwa T, Hara H, Fujimoto J, Sano H. Hepatocyte growth factor preserves graft-versus-leukemia effect and T-cell reconstitution after marrow transplantation. Blood. 2004; 104: 1542-1549.

4. Le Blanc K, Mougiakakos D. Multipotent mesenchymal stromal cells and the innate immune system. Nature reviews Immunology. 2012; 12: 383-396.

5. Baron F, Lechanteur C, Willems E, Bruck F, Baudoux E, Seidel L, Vanbellinghen JF, Hafraoui K, Lejeune M, Gothot A, Fillet G, Beguin Y. Cotransplantation of mesenchymal stem cells might prevent death from graft-versus-host disease (GVHD) without abrogating graft-versus-tumor effects after HLA-mismatched allogeneic transplantation following nonmyeloablative conditioning. Biology of blood and marrow transplantation. 2010; 16: 838-847.

6. Bernardo ME, Ball LM, Cometa AM, Roelofs H, Zecca M, Avanzini MA, Bertaina A, Vinti L, Lankester A, Maccario R, Ringden O, Le Blanc K, Egeler RM, et al. Co-infusion of ex vivo-expanded, parental MSCs prevents life-threatening acute GVHD, but does not reduce the risk of graft failure in pediatric patients undergoing allogeneic umbilical cord blood transplantation. Bone marrow transplantation. 2011; 46: 200-207.

7. Ning H, Yang F, Jiang M, Hu L, Feng K, Zhang J, Yu Z, Li B, Xu C, Li Y, Wang J, Hu J, Lou X, et al. The correlation between cotransplantation of mesenchymal stem cells and higher recurrence rate in hematologic malignancy patients: outcome of a pilot clinical study. Leukemia. 2008; 22: 593-599.

8. Liu K, Chen Y, Zeng Y, Xu L, Liu D, Chen H, Zhang X, Han W, Wang Y, Zhao T, Wang J, Wang J, Han Q, et al. Coinfusion of mesenchymal stromal cells facilitates platelet recovery without increasing leukemia recurrence in haploidentical hematopoietic stem cell transplantation: a randomized, controlled clinical study. Stem cells and development. 2011; 20: 1679-1685.

9. Kuzmina LA, Petinati NA, Parovichnikova EN, Lubimova LS, Gribanova EO, Gaponova TV, Shipounova IN, Zhironkina OA, Bigildeev AE, Svinareva DA, Drize NJ, Savchenko VG. Multipotent mesenchymal stromal cells for the prophylaxis of acute graft-versus-host disease - a phase II study. Stem cells international. 2012; 2012: 968213.

10. Wu KH, Tsai C, Wu HP, Sieber M, Peng CT, Chao YH. Human application of ex vivo expanded umbilical cordderived mesenchymal stem cells: enhance hematopoiesis after cord blood transplantation. Cell transplantation. 2013; 22: 2041-2051.

11. Wang L, Gu ZY, Zhao XL, Wei HP, Luo L, Zhao SS, Liu DH, Wang QS, Gao CJ. [Role of mesenchymal stem cells in preventing GVHD: a meta-analysis]. [Article in Chinese]. Zhongguo shi yan xue ye xue za zhi. 2015; 23: 1125-1132.

12. Kallekleiv M, Larun L, Bruserud O, Hatfield KJ. Co-transplantation of multipotent mesenchymal stromal cells inallogeneic hematopoietic stem cell transplantation: a systematic review and meta-analysis. Cytotherapy. 2016; 18: 172-185.

13. Zinocker S, Wang MY, Rolstad B, Vaage JT. Mesenchymal stromal cells fail to alleviate experimental graft-versus-host disease in rats transplanted with major histocompatibility complex-mismatched bone marrow. Scandinavian journal of immunology. 2012; 76: 464-470.

14. Zhang C, Chen XH, Zhang X, Gao L, Kong PY, Peng XG, Liang X, Gao L, Wang QY. Human umbilical cord bloodderived stromal cells: a new resource in hematopoietic reconstitution in mouse haploidentical transplantation. Transplant Proc. 2010; 42: 3739-3744.

15. Zhang C, Chen XH, Zhang X, Gao L, Kong PY, Peng XG, Liang X, Gao L, Gong Y, Wang QY. Human umbilical cord blood-derived stromal cells, a new resource in the suppression of acute graft-versus-host disease in haploidentical stem cell transplantation in sublethally irradiated mice. J Biol Chem. 2011; 286: 13723-13732.

16. Yoo HS, Yi T, Cho YK, Kim WC, Song SU, Jeon MS. Mesenchymal Stem Cell Lines Isolated by Different Isolation Methods Show Variations in the Regulation of Graft-versushost Disease. Immune network. 2013; 13: 133-140.

17. Yang D, Wang LP, Zhou H, Cheng H, Bao XC, Xu S, Zhang WP, Wang JM. Inducible Costimulator Gene-Transduced Bone Marrow-Derived Mesenchymal Stem Cells Attenuate the Severity of Acute Graft-Versus-Host Disease in Mouse Models. Cell transplantation. 2015; 24: 1717-1731.

18. Yanez R, Lamana ML, Garcia-Castro J, Colmenero I, Ramirez M, Bueren JA. Adipose tissue-derived mesenchymal stem cells have in vivo immunosuppressive properties applicable for the control of the graft-versus-host disease. Stem cells (Dayton, Ohio). 2006; 24: 2582-2591.

19. Xishan Z, Haojun Y, Baoxin H, Xinna Z, Ni J, Hongmei Z, Xiaoli W, Jun R. Mouse Flk-1+Sca-1- mesenchymal stem cells: functional plasticity in vitro and immunoregulation in vivo. Transplantation. 2014; 97: 509-517.

20. Wen F, Zhang HJ, Chen Y, Yue Q, Liu Z, Zhang Q, An N, Chen X, Li N, Xin J, Wang Y, Zhang X, Xu X, et al. Sca1(+) mesenchymal stromal cells inhibit graft-versus-host disease in mice after bone marrow transplantation. International immunopharmacology. 2015; 26: 50-57.

21. Wang YC, Wang SH, Wei YN, Du DW, Xu H, Gao CC, Zheng MH, Xie J, Li JC, Dong GY, Li L, Xiao Y, Han H. Notch-RBP-J signaling is required by bone marrow stromal cells for the treatment of acute graft versus host disease. Stem cell research. 2013; 11: 721-735.

22. Tobin LM, Healy ME, English K, Mahon BP. Human mesenchymal stem cells suppress donor CD4(+) T cell proliferation and reduce pathology in a humanized mouse model of acute graft-versus-host disease. Clinical and experimental immunology. 2013; 172: 333-348.

23. Tisato V, Naresh K, Girdlestone J, Navarrete C, Dazzi F. Mesenchymal stem cells of cord blood origin are effective 
at preventing but not treating graft-versus-host disease. Leukemia. 2007; 21: 1992-1999.

24. Tian Y, Deng YB, Huang YJ, Wang Y. Bone marrowderived mesenchymal stem cells decrease acute graftversus-host disease after allogeneic hematopoietic stem cells transplantation. Immunological investigations. 2008; 37: $29-42$.

25. Sudres M, Norol F, Trenado A, Gregoire S, Charlotte F, Levacher B, Lataillade JJ, Bourin P, Holy X, Vernant JP, Klatzmann D, Cohen JL. Bone marrow mesenchymal stem cells suppress lymphocyte proliferation in vitro but fail to prevent graft-versus-host disease in mice. Journal of immunology (Baltimore, Md : 1950). 2006; 176: 7761-7767.

26. Song N, Gao L, Qiu H, Huang C, Cheng H, Zhou H, Lv S, Chen L, Wang J. Mouse bone marrow-derived mesenchymal stem cells inhibit leukemia/lymphoma cell proliferation in vitro and in a mouse model of allogeneic bone marrow transplant. Int J Mol Med. 2015; 36: 139-149.

27. Sadeghi B, Heshmati Y, Khoein B, Kaipe H, Uzunel M, Walfridsson J, Ringden O. Xeno-immunosuppressive properties of human decidual stromal cells in mouse models of alloreactivity in vitro and in vivo. Cytotherapy. 2015; 17: 1732-1745.

28. Robles JD, Liu YP, Cao J, Xiang Z, Cai Y, Manio M, Tang EH, Chan GC. Immunosuppressive mechanisms of human bone marrow derived mesenchymal stromal cells in BALB/c host graft versus host disease murine models. Experimental hematology \& oncology. 2015; 4: 13.

29. Ren G, Zhang L, Zhao X, Xu G, Zhang Y, Roberts AI, Zhao RC, Shi Y. Mesenchymal stem cell-mediated immunosuppression occurs via concerted action of chemokines and nitric oxide. Cell stem cell. 2008; 2: 141-150.

30. Prigozhina TB, Khitrin S, Elkin G, Eizik O, Morecki S, Slavin S. Mesenchymal stromal cells lose their immunosuppressive potential after allotransplantation. Experimental hematology. 2008; 36: 1370-1376.

31. Polchert D, Sobinsky J, Douglas G, Kidd M, Moadsiri A, Reina E, Genrich K, Mehrotra S, Setty S, Smith B, Bartholomew A. IFN-gamma activation of mesenchymal stem cells for treatment and prevention of graft versus host disease. European journal of immunology. 2008; 38 : 1745-1755.

32. Oviedo A, Yanez R, Colmenero I, Aldea M, Rubio A, Bueren JA, Lamana ML. Reduced efficacy of mesenchymal stromal cells in preventing graft-versus-host disease in an in vivo model of haploidentical bone marrow transplant with leukemia. Cell transplantation. 2013; 22: 1381-1394.

33. Nevruz O, Avcu F, Ural AU, Pekel A, Dirican B, Safali M, Akdag E, Beyzadeoglu M, Ide T, Sengul A. Immunosuppressive effects of multipotent mesenchymal stromal cells on graft-versus-host disease in rats following allogeneic bone marrow transplantation. Turkish journal of haematology. 2013; 30: 256-262.
34. Min CK, Kim BG, Park G, Cho B, Oh IH. IL-10-transduced bone marrow mesenchymal stem cells can attenuate the severity of acute graft-versus-host disease after experimental allogeneic stem cell transplantation. Bone marrow transplantation. 2007; 39: 637-645.

35. Luz-Crawford P, Torres MJ, Noel D, Fernandez A, Toupet K, Alcayaga-Miranda F, Tejedor G, Jorgensen C, Illanes SE, Figueroa FE, Djouad F, Khoury M. The immunosuppressive signature of menstrual blood mesenchymal stem cells entails opposite effects on experimental arthritis and graft versus host diseases. Stem cells (Dayton, Ohio). 2016; 34 : 456-469.

36. Lu X, Liu T, Gu L, Huang C, Zhu H, Meng W, Xi Y, Li $\mathrm{S}$, Liu Y. Immunomodulatory effects of mesenchymal stem cells involved in favoring type $2 \mathrm{~T}$ cell subsets. Transplant immunology. 2009; 22: 55-61.

37. Lim JY, Park MJ, Im KI, Kim N, Jeon EJ, Kim EJ, Cho ML, Cho SG. Combination cell therapy using mesenchymal stem cells and regulatory T-cells provides a synergistic immunomodulatory effect associated with reciprocal regulation of TH1/TH2 and th17/treg cells in a murine acute graft-versus-host disease model. Cell transplantation. 2014; 23: 703-714.

38. Li ZY, Wang CQ, Lu G, Pan XY, Xu KL. Effects of bone marrow mesenchymal stem cells on hematopoietic recovery and acute graft-versus-host disease in murine allogeneic umbilical cord blood transplantation model. Cell biochemistry and biophysics. 2014; 70: 115-122.

39. Li H, Jiang Y, Jiang X, Guo X, Ning H, Li Y, Liao L, Yao H, Wang X, Liu Y, Zhang Y, Chen H, Mao N. CCR7 guides migration of mesenchymal stem cell to secondary lymphoid organs: a novel approach to separate GvHD from GvL effect. Stem cells (Dayton, Ohio). 2014; 32: 1890-1903.

40. Li H, Guo Z, Jiang X, Zhu H, Li X, Mao N. Mesenchymal stem cells alter migratory property of $\mathrm{T}$ and dendritic cells to delay the development of murine lethal acute graftversus-host disease. Stem cells (Dayton, Ohio). 2008; 26: 2531-2541.

41. Li A, Zhang Q, Jiang J, Yuan G, Feng Y, Hao J, Li C, Gao X, Wang G, Xie S. Co-transplantation of bone marrow stromal cells transduced with IL-7 gene enhances immune reconstitution after allogeneic bone marrow transplantation in mice. Gene therapy. 2006; 13: 1178-1187.

42. Lee ES, Lim JY, Im KI, Kim N, Nam YS, Jeon YW, Cho SG. Adoptive Transfer of Treg Cells Combined with Mesenchymal Stem Cells Facilitates Repopulation of Endogenous Treg Cells in a Murine Acute GVHD Model. PloS one. 2015; 10: e0138846.

43. Kitazawa Y, Li XK, Xie L, Zhu P, Kimura H, Takahara $\mathrm{S}$. Bone marrow-derived conventional, but not cloned, mesenchymal stem cells suppress lymphocyte proliferation and prevent graft-versus-host disease in rats. Cell transplantation. 2012; 21: 581-590. 
44. Kim KW, Moon SJ, Park MJ, Kim BM, Kim EK, Lee SH, Lee EJ, Chung BH, Yang CW, Cho ML. Optimization of adipose tissue-derived mesenchymal stem cells by rapamycin in a murine model of acute graft-versus-host disease. Stem cell research \& therapy. 2015; 6: 202.

45. Kikuchi-Taura A, Taguchi A, Kanda T, Inoue T, Kasahara Y, Hirose H, Sato I, Matsuyama T, Nakagomi T, Yamahara K, Stern D, Ogawa H, Soma T. Human umbilical cord provides a significant source of unexpanded mesenchymal stromal cells. Cytotherapy. 2012; 14: 441-450.

46. Joo SY, Cho KA, Jung YJ, Kim HS, Park SY, Choi YB, Hong KM, Woo SY, Seoh JY, Cho SJ, Ryu KH. Mesenchymal stromal cells inhibit graft-versus-host disease of mice in a dose-dependent manner. Cytotherapy. 2010; 12: 361-370.

47. Jang YK, Kim M, Lee YH, Oh W, Yang YS, Choi SJ. Optimization of the therapeutic efficacy of human umbilical cord blood-mesenchymal stromal cells in an NSG mouse xenograft model of graft-versus-host disease. Cytotherapy. 2014; 16: 298-308.

48. Jang MJ, Kim HS, Lee HG, Kim GJ, Jeon HG, Shin HS, Chang SK, Hur GH, Chong SY, Oh D, Chung HM. Placentaderived mesenchymal stem cells have an immunomodulatory effect that can control acute graft-versus-host disease in mice. Acta haematologica. 2013; 129: 197-206.

49. Im KI, Park MJ, Kim N, Lim JY, Park HS, Lee SH, Nam YS, Lee ES, Lee JH, Cho ML, Cho SG. Induction of mixed chimerism using combinatory cell-based immune modulation with mesenchymal stem cells and regulatory T cells for solid-organ transplant tolerance. Stem cells and development. 2014; 23: 2364-2376.

50. Hinden L, Shainer R, Almogi-Hazan O, Or R. Ex Vivo Induced Regulatory Human/Murine Mesenchymal Stem Cells as Immune Modulators. Stem cells (Dayton, Ohio). 2015; 33: 2256-2267.

51. Hao L, Gao L, Chen XH, Zou ZM, Zhang X, Kong PY, Zhang C, Peng XG, Sun AH, Wang QY. Human umbilical cord blood-derived stromal cells prevent graft-versushost disease in mice following haplo-identical stem cell transplantation. Cytotherapy. 2011; 13: 83-91.

52. Guo J, Yang J, Cao G, Fan H, Guo C, Ma YE, Qian Y, Chen $\mathrm{L}$, Li X, Chang C. Xenogeneic immunosuppression of human umbilical cord mesenchymal stem cells in a major histocompatibility complex-mismatched allogeneic acute graft-versus-host disease murine model. European journal of haematology. 2011; 87: 235-243.

53. Gregoire-Gauthier J, Selleri S, Fontaine F, Dieng MM, Patey N, Despars G, Beausejour CM, Haddad E. Therapeutic efficacy of cord blood-derived mesenchymal stromal cells for the prevention of acute graft-versushost disease in a xenogenic mouse model. Stem cells and development. 2012; 21: 1616-1626.

54. Girdlestone J, Pido-Lopez J, Srivastava S, Chai J, Leaver N, Galleu A, Lombardi G, Navarrete CV. Enhancement of the immunoregulatory potency of mesenchymal stromal cells by treatment with immunosuppressive drugs. Cytotherapy. 2015; 17: 1188-1199.

55. Gao L, Liu F, Tan L, Liu T, Chen Z, Shi C. The immunosuppressive properties of non-cultured dermalderived mesenchymal stromal cells and the control of graftversus-host disease. Biomaterials. 2014; 35: 3582-3588.

56. Deng Y, Guo X, Yuan Q, Li S. Efficiency of adenoviral vector mediated CTLA4Ig gene delivery into mesenchymal stem cells. Chinese medical journal. 2003; 116: 1649-1654.

57. Chung NG, Jeong DC, Park SJ, Choi BO, Cho B, Kim HK, Chun CS, Won JH, Han CW. Cotransplantation of marrow stromal cells may prevent lethal graft-versus-host disease in major histocompatibility complex mismatched murine hematopoietic stem cell transplantation. International journal of hematology. 2004; 80: 370-376.

58. Christensen ME, Turner BE, Sinfield LJ, Kollar K, Cullup H, Waterhouse NJ, Hart DN, Atkinson K, Rice AM. Mesenchymal stromal cells transiently alter the inflammatory milieu post-transplant to delay graft-versushost disease. Haematologica. 2010; 95: 2102-2110.

59. Chen W, Li M, Li Z, Yan Z, Cheng H, Pan B, Cao J, Chen $\mathrm{C}$, Zeng L, Xu K. CXCR4-transduced mesenchymal stem cells protect mice against graft-versus-host disease. Immunology letters. 2012; 143: 161-169.

60. Bruck F, Belle L, Lechanteur C, de Leval L, Hannon M, Dubois S, Castermans E, Humblet-Baron S, Rahmouni $\mathrm{S}$, Beguin Y, Briquet A, Baron F. Impact of bone marrowderived mesenchymal stromal cells on experimental xenogeneic graft-versus-host disease. Cytotherapy. 2013; 15: 267-279.

61. Badillo AT, Peranteau WH, Heaton TE, Quinn C, Flake AW. Murine bone marrow derived stromal progenitor cells fail to prevent or treat acute graft-versus-host disease. Br J Haematol. 2008; 141: 224-234.

62. Auletta JJ, Eid SK, Wuttisarnwattana P, Silva I, Metheny L, Keller MD, Guardia-Wolff R, Liu C, Wang F, Bowen T, Lee Z, Solchaga LA, Ganguly S, et al. Human mesenchymal stromal cells attenuate graft-versus-host disease and maintain graft-versus-leukemia activity following experimental allogeneic bone marrow transplantation. Stem cells (Dayton, Ohio). 2015; 33: 601-614.

63. Cooke KR, Kobzik L, Martin TR, Brewer J, Delmonte J, Jr., Crawford JM, Ferrara JL. An experimental model of idiopathic pneumonia syndrome after bone marrow transplantation: I. The roles of minor $\mathrm{H}$ antigens and endotoxin. Blood. 1996; 88: 3230-3239.

64. Sterne JAC, Egger M, Moher D. Addressing reporting biases. In: Higgins JPT, Green S, editors. Cochrane Handbook for Systematic Reviews of Interventions. 2008.

65. Li W, Ren G, Huang Y, Su J, Han Y, Li J, Chen X, Cao K, Chen Q, Shou P, Zhang L, Yuan ZR, Roberts AI, et al. Mesenchymal stem cells: a double-edged sword in regulating immune responses. Cell death and differentiation. 2012; 19: 1505-1513. 
66. Vu Q, Xie K, Eckert M, Zhao W, Cramer SC. Meta-analysis of preclinical studies of mesenchymal stromal cells for ischemic stroke. Neurology. 2014; 82: 1277-1286.

67. Moll G, Alm JJ, Davies LC, Von Bahr L, Heldring N, Stenbeck-Funke L, Hamad OA, Hinsch R, Ignatowicz L, Locke M, Lönnies H, Lambris JD, Teramura Y, et al. Do cryopreserved mesenchymal stromal cells display impaired immunomodulatory and therapeutic properties? Stem Cells. 2014; 32: 2430-2442.

68. Zeiser R, Blazar BR. Preclinical models of acute and chronic graft-versus-host disease: how predictive are they for a successful clinical translation? Blood. 2016; doi: 10.1182/blood-2016-02-699082.

69. Markey KA, MacDonald KP, Hill GR. The biology of graft-versus-host disease: experimental systems instructing clinical practice. Blood. 2014; 124: 354-362.

70. Macleod MR, O'Collins T, Howells DW, Donnan GA. Pooling of animal experimental data reveals influence of study design and publication bias. Stroke. 2004; 35: 1203-1208.

71. DerSimonian R, Laird N. Meta-analysis in clinical trials. Controlled clinical trials. 1986; 7: 177-188.

72. Sterne JA, Sutton AJ, Ioannidis JP, Terrin N, Jones DR, Lau J, Carpenter J, Rucker G, Harbord RM, Schmid CH, Tetzlaff J, Deeks JJ, Peters J, et al. Recommendations for examining and interpreting funnel plot asymmetry in metaanalyses of randomised controlled trials. BMJ (Clinical research ed). 2011; 343: d4002.

73. Egger M, Davey Smith G, Schneider M, Minder C. Bias in meta-analysis detected by a simple, graphical test. BMJ (Clinical research ed). 1997; 315: 629-634.

74. Duval S, Tweedie R. Trim and fill: A simple funnel-plotbased method of testing and adjusting for publication bias in meta-analysis. Biometrics. 2000; 56: 455-463. 